\title{
Léopold Sédar Senghor's Translations and the Trajectory of a World Writer
}

\author{
KATHLEEN SHIELDS \\ National University of Ireland, Maynooth, Ireland
}

Senghor's seldom-studied translations (grouped with his juvenilia and published in Euvre poétique in 1964) illustrate a process of identity formation whereby he can variously represent France, Senegal, Africa, and poetry, ultimately coming to occupy a position as world writer. My analysis of these texts takes into account recent articles on translation and African writers: what did Senghor translate, how did he translate, why did he translate, and why did he stop translating? Strategies of universalizing, flattening, and mystification reveal a process of acculturation rather than cultural crossfertilization. Central to my argument is the contrast between Senghor's concept of métissage and the more current use of the term as Antoine Berman applies it to translation. One optimistic narrative is that as decolonization takes place, more and more translation, increased mutual cultural understanding, and hybridization also occur. Senghor's translations are part of another process, where translation from African languages is abandoned in favour of a world language and its tributaries. They also illustrate features common to other world writers. Once completed, there is no further need for translation to take place.

KEYWORDS Léopold Sédar Senghor, translation, métissage, acculturation, world literature, Antoine Berman

How can one man, Léopold Sédar Senghor, embody two such contradictory values as francophonie, or French as a universal language, and négritude, or writing as a Black African? The contradiction is evident in his essay about the French language published in Esprit in I962. I propose in this article to explore the part that translation plays in allowing for négritude and francophonie to coexist in Senghor's mind. Translation is one place that allows for the passage from Black African to champion of a certain view of the French language. Senghor's translations sample and anthologize a variety of African languages and genres, transforming them into a French that, while not exactly homogenous, appeals to universal values. My argument is that translation plays an important part in the building of Senghor's reputation as world writer. 
The universal value of French language and culture corresponds to the flattening and universalizing of the African languages and cultures from which he draws the translated texts. The translations are a necessary step on his path to the status of world writer and can be understood with reference to his biography, in particular to Senghor's understanding of métissage. In many optimistic accounts in translation studies (for example, in the way that Antoine Berman enlists the term métissage), it is assumed that translation serves the process of decolonization and intercultural exchange. Senghor's translations are an interesting counter-example to this view. Indeed, at a specific phase in his career their function was to redraw literary world maps in such a way as to suit the trajectory of a world author.

\section{Francophonie or négritude?}

In an essay published in the Parisian journal Esprit in I962, Senghor proclaims a metropolitan and gallocentric view of the French language. Here the Senegalese writer is more French than the French themselves, echoing Antoine Rivarol's eighteenth-century essay on the French language. Senghor appeals to such Enlightenment concepts as rayonnement when he states that French is the 'Soleil qui brille hors de l'Hexagone' and that 'son rayonnement ne fait que s'étendre, même au Mali, même en Guinée’ (Senghor, I962: 844, 837). According to Senghor, French not only radiates its clarity and purity from the centre, but it is also better than African languages, due to its abstract vocabulary and subordinating syntax.

Explaining why French is attractive to African élites, he praises what he sees as the inherently superior qualities of the language, particularly its humanism and its universality: 'À la syntaxe de juxtaposition des langues négro-africaines, s'oppose la syntaxe de subordination du français; à la syntaxe du concret vécu, celle de l'abstrait pensé: pour tout dire, la syntaxe de la raison à celle de l'émotion' (Senghor, I962: 840). Others have taken issue with the sharp dichotomy laid out here and elsewhere in Senghor's writings: French equals reason; African languages equal emotion (Adotevi, I988: 45). For the moment, I wish to focus on Senghor as the champion of a certain idea of French - rational, clear, pure, Greco-Roman. He was an important contributor to resilient neo-colonial and universalist ideas about the French language, ideas that are still enshrined in much French language legislation and that have been criticized outside the metropolitan centre. Moreover, he became increasingly monolingual throughout his career, writing and using only French and drawing on its classical tributaries, particularly ancient Greek.

Europeans, accustomed to the idea of a congruence between national literature, language, and nation-state, are perhaps puzzled and even shocked that Senghor as writer and president of Senegal can extol French in this way. He might be expected to write in or to translate from a Senegalese language or languages, at least some of the time. Introducing Senghor's Anthologie de la nouvelle poésie nègre et malgache de langue française in I948, Sartre's preface 'L'Orphée noir' reflects this European perspective on language and identity: 'ce qui risque de freiner dangereusement l'effort des noirs pour rejeter notre tutelle, c'est que les annonciateurs de la négritude sont contraints de rédiger en français leur évangile' (Senghor, I985: xviii). 
At the time of his essay in Esprit, Senghor is at an established phase of his career and an establishment figure, the man who would be elected to the Académie Française in 1983. However, behind the article there is a more complex reality. As one commentator remarks, we often have the feeling, when reading about his life, that 'Senghor appartient à cette catégorie d'hommes à qui le cliché colle à la peau [...] et dont l'histoire ressemble à un conte édifiant' (Olivieri, I998: I03). Senghor himself played a part in creating this moral tale, but the historical moments of the multiple and contradictory positions have to be borne in mind when approaching his work.

The concept of négritude has never really recovered from the criticism levelled at Senghor by other African writers, such as Cheikh Anta Diop, Marcien Towa, and Stanislas Spéro Adotevi, during and after the Pan-African festival in Algiers in I969. Adotevi argues that by 1969 the concept had well outlived its moment of political usefulness. More specifically, he singles out the two contradictory sides of Senghor's thought. One is the useful side of négritude, the 'prise de conscience politique' necessary in the I930s in a period of high colonialism in France (Adotevi, I998: 32). The other is the collection of essentialist ideas about the African mind and African spirituality and intuition that leave out large tracts of history and even true shared experience (Adotevi, I998: 59, 6I, 45). Translation is one of the mechanisms by which Senghor can pass from an empowering 'prise de conscience' to the reverse side of outdated attitudes toward race and language. The translations can shed light on a particular point where several facets of the life connect - the representative of Senegal, the representative of Africa, the representative of French as a world language. Conversely, his biography (particularly Senghor's own understanding of métissage) can help us understand the role of translation in career building. ${ }^{\mathrm{I}}$ What Senghor chose to remember and make public was influenced by the pressures of success and achievement, as well as by the desire to present himself as the perfect example of a man both black and French who blended the best of both into a single personality.

Senghor's vocal and lifelong commitment to a certain vision of the French language can explain why so little, if any, attention has been paid to the small body of translations from African languages included at the back of Euvre poétique in I964. As non-translating writer, he has been contrasted with his compatriot Sembene Ousmane, who writes in French, makes films in Wolof, and also translates into this language (Jones, I987: 4). Jacques Chevrier groups Senghor among 'les inconditionnels', or those who are unqualified in their belief in the French language, while others such as Sembene Ousmane or Birago Diop are described as 'les réticents', those who have doubts and misgivings about using French (Chevrier, cited in Bandia, 2006: 352). For this reason Senghor's own translations are interesting, insofar as they are one point where the writer in French meets the cultures of his birth, and because they play a part in the very creation of Senghor as Francophone world writer.

The translations are a point of contact between facets kept apart elsewhere in Senghor's life and work. These facets are allowed to coexist in the translations, juxtaposing négritude and francophonie without necessarily bridging them, blending them, or reconciling them. Translation is often cited as the way in which literatures and cultures are brought into contact. However, it can also be the case that once 
translations are done they can be used in order to keep literatures apart, and in order to draw literary world maps in a certain way. This would appear to be true of Senghor's translations. It is tempting to use translation as part of the trope of reconciliation of contradictions. However, the interaction between translation and biography can show a contradiction being maintained without really being reconciled.

\section{The translations}

The translations from Senegalese and other languages are a small and rather hidden part of Senghor's work, grouped at the back of his complete poems and included at the same time as poèmes perdus, a selection of poems which, according to the author, were written in his youth and kept by his wife because she thought they were worth republishing (Senghor, I990: 5). They correspond broadly to the term 'authorized translations' as Moradewun Adejunmobi uses it. With authorized translations there is some kind of original text that precedes the translations that are presented. At the same time 'the fact of translation hardly impacts on language use within the European language version and functions rather as a strategy for ethnic identification of the European-language text [...] Despite their original versions, these texts may be regarded as also belonging to the genus of African writing in European languages' (I998: I65-66, I70). It is quite possible that they are also compositional or imaginary translations, as Senghor covers the traces of their origins.

The translations in question are five transcribed oral texts of varying length and genre translated from Bantu, Bambara, Pulaar, and Khassonke. Where did the texts come from? There is no straightforward answer to the question of what original texts Senghor translates since there are two things at issue, namely the matter of what constitutes a text and the matter of orality. In the European context translating has meant putting a written text into another language in written form (often transferring texts from languages used by largely monolingual groups). It has been observed that this is not the case in the African context. For example, Bassay Antia, commenting on book translation in Nigeria, states that there has always been a concept of interpreting (or, of oral translation) but that when it comes to printed texts readers have very little awareness of whether they have been translated or not. In other words, there is a non-perception of translation in the minds of the reading public (Antia, I999).

This distinction is helpful in approaching Senghor's translated texts. As African writer he does not specify the mode of transmission of these oral texts or whether one or multiple source texts are being used. He adopts different positions in relation to his source texts, even within this small body of translations. The paratexts only describe two of the poems as being translated ('traduits') while the other three are simply presented as songs, 'chant bantou', 'chant bambara du Mali', and 'chant de guerre bambara'. As Paul Bandia says, it is often the case that with African translations 'the translation is not based on any particular concrete source-language text, but rather it is inspired by the general folklore or oral tradition' (2006: 355). The original can be written from a metatext of culture. 
To the European reader the vagueness about the process of translation, whether in regard to sources, intermediary texts, or collaboration, appears to be deliberate mystification. Mystery about sources also suits the promotion from national author to world writer and is not an unusual feature of world writers in their use of translations (it occurs, for example, in Nobel prize winners like W.B. Yeats and Seamus Heaney). Given that Senghor attended a French-language Catholic boarding school from a very young age, a large part of his cultural formation was works by canonical French authors. As he says, his first authors were Hugo, Baudelaire, Rimbaud, Mallarmé, Valéry, Claudel, and Saint-John Perse (I990: 370). He also describes how in his village before the age of ten he listened to oral poetry recited by women whom he does not name but calls his three Graces ('les poétesses populaires de mes villages d'enfance'). Bernard Mouralis mentions that Senghor collaborated with one of these village women poets named Marône; Senghor indeed mentions her in the afterword to Éthiopiques (Mouralis, 200I: I785). However, he himself keeps his sources mysterious and anonymous in his translations.

This brings me to the second question of how Senghor translates, or, more precisely, of the effect of his translations on the French-speaking reader. The first impression is of a flattening of form and tone, regardless of which language or genre the texts are from. For example, the love song 'L'oiseau d'amour' begins:

Mais laisse-moi, ô Dyambéré!

Toi qui portes l'écharpe aux franges longues,

Laisse-moi chanter les oiseaux.

Les oiseaux qui écoutèrent la Princesse en allée

Et reçurent ses confidences dernières. (I990: 4IO)

Compare this with the similar syntax and simplicity of tone in the war song 'Dongo le Vautour':

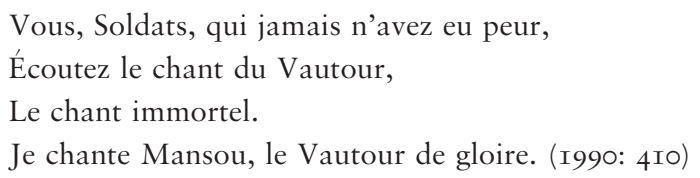

Here, as in all five translations, Senghor combines, on the one hand, features of oral language (refrains, interjections, questions, and direct address or allocution) with, on the other hand, a neutral to formal, even highly literary, register.

The 'Ballade Khassonkée de Dioudi' opens with a direct address to the young girls in the audience: 'Jeunes filles, dont le regard sait si bien faire battre le Cœur des hommes les plus froids, vous qui pouvez, d'un coup d'œil, faire plus de mal que le fusil [...]'. The register soon switches to the literary vocabulary of the chanson de geste: 'Bakary était un grand roi, qui commandait à tout le Bakounou. Son nom était vénéré par les habitants de cent villages et faisait l'effroi de ses ennemis, parce qu'il avait grand nombre de vaillants guerriers dont la bravoure était irrésistible' [my italics] (I990: 420).

The two long narrative texts clearly show signs of being transposed from oral forms: the 'Ballade Khassonkée de Dioudi', is a tale of a young princess, Dioudi, who dies for love, and it often breaks off with direct address to the different sections of an imaginary audience, whether to all present in the form of proverb ('Mais, 
hélas! hélas! le bonheur n'a qu'un jour, le malheur dure toute la vie' (I990: 422)) or finally to the young men at the close: 'Guerriers qui faites trembler l'ennemi [...] écoutez l'histoire de Séga, qui est mort d'amour' (I990: 426). The other narrative, a praise poem and battle song about a hero called Samba, repeats the same refrain throughout: 'Il est parti Samba!'.

An interesting example of the combining of oral with highly literary features is the translation 'Chant du Feu'. In one of his essays Senghor states that he translated this poem himself (I990: 395) but without saying whether he got help from anyone else.

Feu que les hommes regardent dans la nuit, dans la nuit profonde,

Feu qui brûles et ne chauffes pas, qui brilles et ne brûles pas,

Feu qui voles sans corps, sans cœur, qui ne connais ni case ni foyer,

Feu transparent des palmes, un homme sans peur t'invoque.

Feu des sorciers, ton père est où? Ta mère est où? Qui t'a nourri?

Tu es ton père, tu es ta mère, tu passes et ne laisses traces.

Le bois sec ne t'engendre, tu n'as pas les cendres pour filles, tu meurs et ne meurs pas.

(I990: 409)

This far the text shows clear signs of connection to a tradition of riddles, kennings, and paradoxes ('tu meurs et ne meurs pas', 'tu es ton père, tu es ta mère'). The register is neutral, as it is in the very similar 'Dongo le Vautour'. However, in places it shifts from a neutral to a Latinate and literary French, inventing new words from Latin in the manner of French Renaissance poetry:

Feu des sorciers, Esprit des eaux intérieures, Esprit des airs supérieurs, Fulgore qui brilles, luciole qui illumines le marais [my italics]. (I990: 409)

A luciole is a firefly, but what is a fulgore - perhaps a sort of lightening spirit? It seems that Senghor is not only writing from an African 'metatext of culture' but also appealing to a European, specifically French, classical, and written 'metatext of culture'.

This is particularly the case in the narrative 'Ballade Toucoulore de Samba-Foul' (translated from the Peul). Common motifs of oral literature stand out, such as the jealous uncle who deprives the heir to the throne of his rightful succession, and the lost sandal as a sign that Samba is the true heir. Again a neutral register is used, but, for the French-speaking reader, literary and Latinate vocabulary also brings the story close to classical myths (the story of Jason, for example). After his uncle seizes power Samba is banished and goes to an ally:

Samba est arrivé chez le Tounka de Ouandé, dans le Fouta Damga. Il se fait reconnaître et il est festoyé. Mais son oncle est puissant et le Tounka est faible, de sorte qu'il ne peut recevoir aucun secours d'hommes pour faire la guerre. Il confie au Tounka et ses sœurs, qu'il a sauvées de l'animadversion de son oncle [my italics]. (I990: 4I2-I3)

Animadversion is a startlingly literary and Latinate word to use for blame. While festoyé, used transitively as it is here, to mean 'to celebrate somebody with a feast', is an archaism that can be linked to other references to French chansons de geste in the poem, as well as to the French medieval world. For example Samba is described as the 'suzerain légitime', in an explicit reference to the feudal system, rather than simply as 'seigneur légitime' (I990: 4I8). 
Yvan Leclerc comments that the oral-written distinction is a European fixation that melts away as soon as you start to look at Senghor's poetry (I987: I65). It is true that the translations, like the rest of the poetry, combine oral with highly literary elements to create speckled texts. However, oral features used in this way, once cut off from their context, become literary devices. As Eileen Julien says, 'oral artistic forms are and have always been supple and absolutely contemporaneous'. Moreover, the oral text is created at its moment of performance, 'in the moment of its enunciation and reception, the moment when an audience invests the narrative fabric with meaning' (2003: I23). Because these oral features are framed in literary artefacts, taking them out of their context is part of the process of exhibiting them.

Both the combining of oral and written elements, across all of the translations, along with the other translation strategies present, show very clearly a process where Senghor universalizes two different cultures. By education and background Senghor was well placed to see the similarities between different literatures and to stress these over the differences. The translations flatten the diversity of different literatures, whether in Bantu or Bambara, in order to create a homogenous African literature, while France, specifically in its literary Latinity, represents European and even universal values.

Following his trajectory from exiled student of classics in Paris, to black poet influenced by surrealism, to world author and torchbearer of a certain view of French as a world language, one becomes aware that it is the interstices in Senghor's career that are fascinating. This is as true of his attitude to language as it is of the political sides of his career. His first writings included learned descriptive articles on Senegalese languages (Westley, 2002: 9I), yet in later life he stated that he had forgotten his first language and that it had been displaced by French and classical Greek. In I937, as teacher of classics to French children in Tours, he returned to Dakar and questioned whether it was appropriate for educated West Africans to try to assimilate to French culture, suggesting that their literature should be written in African languages (Vaillant, 2002: I8). Yet he himself did not choose this path.

A clear contrast can be made between the five translations just discussed and the poetry that is not translation. Here Senghor uses juxtaposition rather than complete assimilation to metropolitan French norms. His best-known poems of exile and poems imitating musical forms (such as 'Joal' and 'Que m'accompagnent kôras et balafong') are good examples of texts that gesture toward an African other in an unsettling way. The latter poem has as its epigraph a translation with the original in parallel. In fact, here Senghor briefly adopts the role of translator as mediator, rather than exhibitor (I990: 28).

QUE M'ACCOMPAGNENT KORAS ET BALAFONG

(guimm pour trois kôras et un balafong)

À RENE MARAN

Eléyâi bisimlâi! Mângi dêti woy

Biram Dégén-ô! ndendâ'k tamâ'k sabar-ê!

Eléâye bisimlâye! De nouveau je chante le Noble.

O Biram Déguen! Que m'accompagnent ndeundeus, tamas et sabers!

POÈME WOLOF 
'Joal', named after the poet's birthplace, is perhaps the culminating text of exile and of being in neither one culture nor another (I990: I5-I6). Different musical forms and traditions are contrasted structurally in the carefully punctuated text, so that they resonate in the memory of the narrator for whom the music that most evokes his condition is the orphan jazz of black Americans:

Je me rappelle les voix païennes rythmant le Tantum Ergo

Et les processions et les palmes et les arcs de triomphe.

Je me rappelle la danse des filles nubiles

Les chœurs de lutte - oh! la danse finale des jeunes hommes, buste

Penché élancé, et le pur cri d'amour des femmes - Kor Siga!

Je me rappelle, je me rappelle...

Ma tête rythmant

Quelle marche lasse le long des jours d'Europe où parfois

Apparaît un jazz orphelin qui sanglote sanglote sanglote. (I990: I4)

In the poetry outside the translations, there are areas that remain out of bounds and opaque to the European reader. The use of proper nouns to refer to Senegal, Africa, and childhood has the effect of withholding part of the meaning from the French metropolitan reader (Cardonne-Arlyk, 1987). It has been noted that some of these poems could be described as 'ethno-texts' (Kestelloot, I986: 99). However, a different process is at work in the translations, which are much clearer and more explicit for the European reader. Before the two cultures meet, a labour of acculturation has taken place whereby Senghor creates a unified African culture on the one side and a unified French culture on the other. The translation strategies play an important part on the African side, while the French language is the unifying and centralizing force in French culture.

\section{Métissage, hybridity, and acculturation}

Translation is often perceived as a means of decolonization and mutual understanding. However, it can be argued that Senghor used it in a very different way to develop and facilitate his position as world writer. A clear illustration of this point lies in the differences between the concept of métissage as used by Senghor and the meanings that the term has since come to acquire in cultural and translation studies, specifically as Antoine Berman uses it. Berman wrote in relation to the ethical demands of translation, 'l'essence de la traduction est d'être ouverture, dialogue, métissage, décentrement. Elle est mise en rapport, ou elle n'est rien' (I984: I6). The term métissage is highly polysemous in French and often gives rise to terminological confusion. Originally it meant the mixing of two threads in a fabric (in I834), and subsequently the mixing of different races, or hybridization in zoology or botany. Figuratively the expression métissage culturel came to be used to mean cultural cross-fertilization (or multi-culturalism in a whole society). Latterly the culturel has tended to be dropped, as in Berman's statement about translation. It is interesting to note that for Edouard Glissant the term métissage is to be avoided, since it has too strong a connection to identity politics and to race, tribe, or birth (I996: I8-20). He prefers the related 
term créolisation, as it conveys the idea of an unpredictable process of constantly renewable and historically changing interactions between birth, language, and culture.

Returning to Berman, he uses the word métissage in a European context in order to counteract what he calls ethnocentrism in translation, the dominance of one language, culture, and nation-state. He admires the openness of German Romantics (particularly Hölderlin, but also Schleiermacher and Goethe) to other languages and cultures at a time when they had no obvious nation-state. So when he says that translation involves 'ouverture, décentrement', it is clear that he means decentring from a strong monolingual base and national literature. Although Berman does not dwell on questions of origins, whether of tribe, nation, or religion, he conjures them up by the very use of the words métissage and ethnocentrism.

Unlike Berman's métissage, Senghor's métissage functions in two ways, firstly by keeping different roles apart and as non-connecting facets, and secondly by allowing Senghor to be representative of different things at any given time. As he says himself, like many a writer he is the product of a biological mix, 'ce métissage biologique' (I990: 370). But more important is his mixed cultural heritage: 'Encore que je sois culturellement enraciné dans la sérérité, mon père, serère, était de lointaine origine malinké avec un nom et, probablement, une goutte de sang portugais, tandis que ma mère, serère, était d'origine peule' [1990: 370; italics in the original]. From this biological and cultural fusion he creates Senegalese identity.

In the collaborative 'Dialogue sur la poésie francophone' the three metropolitan French-language writers, Pierre Emmanuel, Alain Bosquet, and Jean-Claude Renard need Senghor as much as, if not more than he needs them. They need his work and his translations in French because for them he is a representative figure. For the Belgian writer Bosquet, Senghor represents his people, the people of Senegal, while for Emmanuel and Renard he is simply 'l'Africain', thereby representing the whole continent of Africa (I990: 36I-62, 365-67). So Senghor as a writer is metonymic twice over - a part or a facet can stand for the whole. The translations perform a similar function. As they are works that represent Senegal and Africa and expressed with the clarity and universality of the French language, they play an important part in the trajectory and validation of the world author.

Translation for Senghor involves presenting a unified culture (the literature of black Africa) to another cultural zone (literature in French). As he writes in 1958 in his preface to a book of stories by Diop: 'Voilà quelque cent cinquante ans que les blancs s'intéressent à la littérature des nègres d'Afrique [...] Mais voilà que les Négro-africains de langue française veulent eux-mêmes manifester cette littérature, et ils se présentent en traducteurs le plus souvent' (Diop, 1958: 7). It is interesting that he sees translation as manifesting a literature. An important aspect of translation is representation, whereby a translation constructs an image while also exhibiting it (Tymoczko, 2006: 28). Translation itself is performative and constitutive in that it manifests a literature, and while the universal cultural zones are being manifested, they are also being invented.

Throughout his career Senghor adopted a diffusionist model of cultures drawn from the German ethnologist Leo Frobenius, in particular the idea of aires culturelles or cultural zones. The translation's function is then to interpret one of these 
universals, the African, for the other, the French. Translating plays an important part in illustrating, constructing, and exhibiting a homogenous African zone. For instance, in one essay he samples the first few lines of 'Chant du feu', one of his translations already mentioned, along with short excerpts of other translated texts to illustrate what he calls the 'vertus de la parole poétique nègre'. He uses the beginning of this translation to show how black poetry juxtaposes concrete with concrete image, repeats key words, and has its own rhythm and melody (I990: 394). This he distinguishes from French writing which, he says, joins concrete with abstract images. His statement on the literatures arising within these zones is very similar to his statement in the Esprit article on the characteristics of French and African languages.

Senghor engages in a similar appeal to his brand of métissage between French and African literatures and languages in the many prefaces he wrote for other writers, as Richard Watts notes:

Senghor's prefaces and their ambiguities are completely consonant with the rest of Senghor's career, animated as it was by his desire to be a go-between, a figure who is both Senegalese and French, a bridge between what he views as two distinct cultures. Senghor was a fervent proponent, especially later in life, of the métissage of these two cultures. But Senghor's version of métissage was based, as his prefaces show, on a notion of original purity. (2002: 85 )

As Watts says, later black preface writers like Glissant and Lopes stress that cultures are already mixed, if not always already mixed. While Senghor desired in his life and his politics to be a bridge between France and Africa, it is very important to distinguish at this point of the argument between the life and the translation strategies that he uses. The metaphor of the bridge is an overused and underexamined one in translation studies. If one were to use the bridge metaphor at all to describe Senghor's translations, then it might be to say that the bridge was used for a brief time for traffic to pass in one direction and then forgotten once he became a world writer. A more appropriate metaphor is that of exhibiting or of showcasing samples of African literature. As it applies to translation, métissage, in Senghor's sense of the term, is a joining of clearly-defined cultural zones seen as pure in themselves, and is also very far removed from métissage as Berman understands it. Instead of openness to other languages (ouverture) Senghor proposes translation from many languages into one, French, which will then radiate its clarity and universality throughout the world (rayonnement). Instead of Berman's decentring, Senghor proposes acculturation, or adapting to a cultural centre of gravity, first African, then French. He then brings about a meeting of the two (or a métissage in his sense of the term).

In his translations Senghor flattens, he universalizes, and he mystifies. These strategies are used in order to represent and to exhibit his culture, not just Senegalese but also African, on a world stage. The translations are a step in the career trajectory of a world writer because once they have been undertaken and completed there is no further need for translation. As Michael Cronin puts it in the context of tourism, it is possible for the need for translation to disappear: 'It is resistance to translation, not acceptance, that generates translation. If a group of individuals or a people agree to translate themselves into another language, that is if they accept translation unreservedly, then the need for translation also disappears. For the translated there 
is no more translation' (2000: 95). We could add that, when an individual embraces the other language as unreservedly as Senghor embraced French, then the need for translation also disappears. While he translated in order to represent his country in the united nations of world literature, this motive can also explain why he stopped translating.

Senghor's translations are an interesting case because they show that not all post-colonial African translators necessarily use translation to resist the Empire or to write back against its language. In an analogous way we can consider colonialism in the history of a people. It has been argued that retrospective distinctions are important when considering the history of colonialism: 'If, some considerable time after a conquest, the conquered population comes to accept the state into which their ancestors had been forcibly inducted as legitimate, then what has been happening is state-building. If they do not, it is colonialism' (Howe, 2000: I9). Nevertheless, the fact that some translations do not fit a pattern of post-colonial resistance is not a sufficient reason for not studying them.

For Senghor to translate into French, and then to champion that language while ceasing to translate, was all part of representing a literature on the world stage. It helps the career of a world writer to compose in a world or a much-used language. A world writer tends to tell us far less about his or her culture than a lesser-known or minor writer from the same culture (to take the contrast between Senghor and Sembene Ousmane, for instance). A world writer is awarded many literary prizes by countries outside his or her own (certainly true of Senghor) and is translated into many other languages. Bibliographies, library catalogues, and databases list the many translations of Senghor rather than the small number of translations that are done by him. A further sign of Senghor's success on the world stage is that at the end of his career he did a translation from one world language into another, from English into French (Senghor, 200I).

To conclude, and to situate Senghor's translations in relation to translation studies, they do not represent a decentring or a métissage in Berman's sense, but rather offer a landscape where two ethnocentric centres (Africa and France) can be joined. There is an inherent optimism in Berman's statement that the relationships brought about by translation necessarily entail decentring and dialogue. This optimism is not unique to Berman and indeed pervades translation studies. A few have questioned it. Douglas Robinson, for example, has drawn attention to a metanarrative of postcolonial translation studies whereby cultures are seen to progress through certain stages: the precolonial state, the colonial state, the postcolonial state, and a future decolonized state (1997: 89-90). Against the backdrop of optimistic views, Senghor's translations present an interesting case. It is often assumed that decolonization leads to more and more translation. However, translation was important to him only while he was elaborating an African cultural zone, but faded into the background as he became a world writer.

\section{Note}

I I follow the approach of Jean Delisle and Judith Woodsworth (I995). Translators' work is situated

in relation to their lives while their lives are also situated in their historical moment. 


\section{References}

Adejunmobi, M. 1998. Translation and Postcolonial Identity: African Writing and European Languages. The Translator, 4(2): I63-8I.

Adotevi, S.S. 1998. Négritude et négrologues. Paris: L'Harmattan.

Antia, B. I999. La Traduction en anglais de la littérature francophone: Perception du phénomène au Nigéria. Meta, 44(3) [accessed I5 June 2007]. Available at: <http://www.erudit.org/revue/metar999/v44/n3 >

Bandia, P. 2006. African Europhone Literature and Writing as Translation: Some Ethical Issues. In: T. Hermans, ed. Translating Others. Manchester: St Jerome, pp. 349-6I.

Berman, A. I984. L'Epreuve de l'étranger: Culture et traduction dans l'Allemagne romantique. Paris: Gallimard. Cardonne-Arlyck, E. I987. Effets de noms. Sud, special issue: 28-43.

Cronin, M. 2000. Across the Lines: Travel, Language, Translation. Cork: Cork University Press.

Delisle, J. and Woodsworth, J. eds. 1995. Les Traducteurs dans l'histoire. Ottawa: Presses de l'Université d'Ottawa.

Diop, B. 1958. Les Nouveaux contes d'Amadou Koumba. Paris: Présence Africaine.

Glissant, E. I996. Introduction à une poétique du divers. Paris: Gallimard.

Howe, S. 2000. Ireland and Empire: Colonial Legacies in Irish History and Culture. Oxford: Oxford University Press.

Jones, T. I987. Some Intra- and Extra-Hexagonal Attitudes to French. French Studies Bulletin, 23: 3-5.

Julien, E. 2003 . Reading 'Orality' in French-Language Novels from Sub-Saharan Africa. In: C. Forsdick and D. Murphy, eds. Francophone Postcolonial Studies. London: Arnold, pp. I22-32.

Kestelloot, L. I986. Comprendre les poèmes de Léopold Sédar Senghor. Issy les Moulineaux: Saint-Paul.

Leclerc, Y. I987. Poésie, oralité, écriture. Sud, special issue: I65-88.

Mouralis, B. 200I. Léopold Sédar Senghor. In: J.-P. de Beaumarchais, D. Couty, and A. Rey, eds. Dictionnaire des écrivains de langue française. Paris: Larousse, pp. $1784-85$.

Olivieri, C. 1998. Senghor: négritude et francophonie. Le Français dans le monde, special issue: 103-04.

Robinson, D. 1997. Translation and Empire: Postcolonial Theories Explained. Manchester: St Jerome.

Senghor, L.S. I962. Le Français, langue de culture. Esprit, 837-44.

Senghor, L.S. 1985. Anthologie de la nouvelle poésie nègre et malgache de langue française. Paris: Presses universitaires de France.

Senghor, L.S. I990. Euvre poétique. Paris: Seuil.

Senghor, L.S. 200I. La Rose de la paix et autres poèmes traduits de l'anglais par Léopold Sédar Senghor avec la collaboration de John Amery. Paris: L'Harmattan.

Tymoczko, M. 2006. Reconceptualizing Western Translation Theory: Integrating Non-Western Thought about Translation. In: T. Hermans, ed. Translating Others. Manchester: St Jerome, pp. I3-32.

Vaillant, J. 2002. Homage to Léopold Sédar Senghor: I906-200I. Research in African Literatures, 33(4): 17-24.

Watts, R. 2002. Senghor's prefaces between the colonial and the postcolonial. Research in African Literatures, $33(4): 76-87$.

Westley, D.M. 2002. A Select Bibliography of the Works of Léopold Sédar Senghor. Research in African Literatures, 33(4): 88-100.

\section{Note on Contributor}

Correspondence to: Kathleen Shields, French Department, National University of Ireland Maynooth (NUI Maynooth), Maynooth, Co. Kildare, Ireland. Email: kathleen.m.shields@nuim.ie 